\title{
Reconsiderations on the Crises of Comparative Literature Study
}

\author{
Jie Lu \\ Chengdu University of Information Technology
}

Follow this and additional works at: https://docs.lib.purdue.edu/clcweb

Part of the American Studies Commons, Comparative Literature Commons, and the European Languages and Societies Commons

Dedicated to the dissemination of scholarly and professional information, Purdue University Press selects, develops, and distributes quality resources in several key subject areas for which its parent university is famous, including business, technology, health, veterinary medicine, and other selected disciplines in the humanities and sciences.

CLCWeb: Comparative Literature and Culture, the peer-reviewed, full-text, and open-access learned journal in the humanities and social sciences, publishes new scholarship following tenets of the discipline of comparative literature and the field of cultural studies designated as "comparative cultural studies." Publications in the journal are indexed in the Annual Bibliography of English Language and Literature (Chadwyck-Healey), the Arts and Humanities Citation Index (Thomson Reuters ISI), the Humanities Index (Wilson), Humanities International Complete (EBSCO), the International Bibliography of the Modern Language Association of America, and Scopus (Elsevier). The journal is affiliated with the Purdue University Press monograph series of Books in Comparative Cultural Studies. Contact: <clcweb@purdue.edu>

\section{Recommended Citation}

Lu, Jie. "Reconsiderations on the Crises of Comparative Literature Study." CLCWeb: Comparative Literature and Culture 19.5 (2017): <https://doi.org/10.7771/1481-4374.3107>

This text has been double-blind peer reviewed by $2+1$ experts in the field.

The above text, published by Purdue University Press @Purdue University, has been downloaded 222 times as of $11 /$ $07 / 19$.

This document has been made available through Purdue e-Pubs, a service of the Purdue University Libraries. Please contact epubs@purdue.edu for additional information.

This is an Open Access journal. This means that it uses a funding model that does not charge readers or their institutions for access. Readers may freely read, download, copy, distribute, print, search, or link to the full texts of articles. This journal is covered under the CC BY-NC-ND license. 


\section{PURDUE}

UNIVERSITY PRESS <http://www.thepress. purdue.edu>

\section{CLCWeb: Comparative Literature and Culture}

ISSN 1481-4374 <http://docs.lib.purdue.edu/clcweb> Purdue University Press @Purdue University

CLCWeb: Comparative Literature and Culture, the peer-reviewed, full-text, and open-access learned journal in the humanities and social sciences, publishes new scholarship following tenets of the discipline of comparative literature and the field of cultural studies designated as "comparative cultural studies." In addition to the publication of articles, the journal publishes review articles of scholarly books and publishes research material in its Library Series. Publications in the journal are indexed in the Annual Bibliography of English Language and Literature (Chadwyck-Healey), the Arts and Humanities Citation Index (Thomson Reuters ISI), the Humanities Index (Wilson), Humanities International Complete (EBSCO), the International Bibliography of the Modern Language Association of America, and Scopus (Elsevier). The journal is affiliated with the Purdue University Press monograph series of Books in Comparative Cultural Studies. Contact: <clcweb@purdue.edu>

Volume 19 Issue 5 (December 2017) Article 7

Jie LU,

"Reconsiderations on the Crises of Comparative Literature Study"

<http://docs.lib.purdue.edu/clcweb/vol19/iss5/7>

Contents of CLCWeb: Comparative Literature and Culture 19.5 (2017)

Special Issue Against the "Death" of the Discipline of Comparative Literature

Ed. Shunqing Cao

<http://docs.lib.purdue.edu/clcweb/vol19/iss5/>

Abstract: In her article "Reconsiderations on the Crises of Comparative Literature Study" Jie Lu discusses the three crises in comparative literature and reaches the conclusion that the discipline's significant changes are due primarily to the three misunderstandings of "comparative literature," that are "narrowing," "overgeneralization," and "trivialization." Narrowing is the over-regulation of study object and horizon, and a narrow understanding of comparability. Overgeneralization exists in cultural studies' aggression to comparative literature and a compromising abandonment of comparative methodology. Finally, trivialization exists in shallow comparison between $X$ and $Y$, monologue-like discourse researches, and a lack of dual awareness of "world literature" as both disciplinary ideal and methodology in a new context. 


\section{Jie LU}

\section{Reconsiderations on the Crises of Comparative Literature Study}

Comparative Literature has been recognized as an autonomous academic discipline for over two centuries. From the first stage of French school's influence studies on basis of positivist paradigm to the second stage of American school's parallel studies on cross-national and cross-disciplinary literature, then to its present third stage of Chinese school's variation studies and general studies on crosscivilization literary works and theories, the study of international comparative literature has witnessed its share of vicissitudes. However, whenever the discipline was in a crisis, it would both diagnose and prescribe for its own malady. In general, the development of international comparative literature study has occurred through three major crises, including the first crisis caused by Croce's accusation of the discipline's comparative methodology and lack of scientificity, the second crisis caused by the undue restriction of the research scope and excessive emphasis on "international literary history," and the third crisis caused by the currents of the cultural turn and pan-cultural study. To counter the first crisis, the French school narrowed the field of possible research objects and imposed the condition of facticty onto the research of literature, but it consequently brought the second crisis described as "a pool of stagnant water" which was a metaphor of lifelessness. Then to solve the second crisis of repressed and narrowed disciplinary pattern typified by French influence studies, the American school proposed parallel studies on literature without factual relations which broke the enclosure set up by the French school. It bears repeating, however, that no solution can work absolutely; no panacea can cure all conditions. The American school's antidote successfully alleviated the discipline's symptoms, but it also opened the "Pandora's box" and generated some adverse effects. Admittedly, after René Wellek's diagnosis of the "symptoms of long-drawn-out crisis", his antidote of "literariness" proposed in his 1958 work has saved the discipline from its second crisis ("The Crisis" 293). Comparative literature study soon recovered and shed its fetters of "relation" and discovered an uncultivated land of more freedom and greater vitality. However, through more than half century of unbridled growth, the temporarily healthy discipline became obese and even outgrew the disciplinary frame and hence gave rise to the third crisis: a crisis caused by the oversize of discipline scope and too loose regulation. In fact, the present third crisis bears down menacingly and is of no less severity than the previous two crises. It has caught the eye of many scholars in this field: Writing in 1993, Susan Bassnett asserted that "Today, comparative literature in one sense is dead. The narrowness of the binary distinction, the unhelpfulness of the ahistorical approach, the complacent shortsightedness of the Literature-as-universal-civilizing-force approach have all contributed to its demise" (Comparative 47). In 1995, Charles Bernheimer prefaced Comparative Literature in the Age of Multiculturalism with his article entitled "The Anxieties of Comparison" (1-7). In 2003, Gayatri Spivak published her book Death of a Discipline (xii). In the same year, Haun Saussy entitled his article in the fourth "ten-year" report for ACLA (American Comparative Literature Association) as "Exquisite Cadavers Stitched from Fresh Nightmares: Of Memes, Hives, and Selfish Genes" (3-42). Words like "crisis," "anxieties," "death," and "cadavers" from leading scholars in the field aroused responses around the world. In the recent two decades, scholars from many countries expressed their opinions on the third crisis in comparative literature study, as apparent from articles such as "Comparative Canadian Literature as Crisis and Critique: Towards Comparative Cultural Studies" (Cavell 7-14), "Comparative Literature and the Crisis of Literary Studies" (Moser 43-50), "Is Comparative Literature in a Crisis?"(Beker 91-100), "Is Comparative Literature Ready for the Twenty-First Century?" (Kushner), "Failed Prediction and Outdated Prescription" (Cao 21-23), "The Permanent Crisis, Or Can, Could or Should Comparative Literary Studies Survive? Between History, Theory and Area Studies" (Pospisil 50-61), "Reflections on the Crisis of Comparative Literature as a Discipline"(Liu 33-42), "Crisis or Future? The Germanic Compared Literature" (Roloff 9-10), "Comparatism and the Crisis of Literary Studies" (Pokrivčák 77-78), and "Comparative Studies Today. Comparative Studies, Crisis..." (Wolski 250-254) to name only a few. The destiny of comparative literature as a discipline has invited seemingly endless debates.

From the above-mentioned examples, it is obvious to us that international comparatists tend to place themselves in one of two camps, with one camp of pessimists and the other not that desperate regarding the destiny of the study. Interestingly, some scholars vacillated or even changed their stands from one camp to the other. For example, in 2006, Susan Bassnett, one of the first clarions of crisis, conceded in "Reflections on Comparative Literature in the Twenty-First Century" that her previous conviction that comparative literature would be replaced by translation study was improper (111). In an interview published in 2010 she explained her changing perspective: "change is always 
confusing and can sometimes also be painful. But there can be no growth, no forward movement without change" (Zhang, "Coming" 47-51). Therefore, the answer to the question whether comparative literature is really dying varies from time to time and person to person. The question "For whom the bell tolls?" in terms of comparative literature as a discipline merits academia's unbiased reconsideration. A retrospect of the development of comparative literature study in the past and a summarization of ideas on the discipline's prospect and fate of scholars from different backgrounds help us to answer the question above: throughout the whole disciplinary history, the bell tolls for three sorts of scholarly critiques which I argue are misunderstandings of the disciplines: those who "narrow", those who "over-generalize," and those who "trivialize" comparative literature study.

As we know, although the French school's influence study is universally acknowledged as the first stage of comparative literature, the discipline can actually be traced much earlier than that. When British scholar Posnett, H.M, author of the first monograph on Comparative Literature (1886), elaborated his understanding of "comparative literature" from perspectives of clan literature, city literature, world literature, and national literature, he harbored a broad and liberal mind to take in both influence studies and parallel studies as his paradigms as well as both intrinsic and exterior literary traits as his study objects. The pre-historical disciplinary theory indeed was quite liberal and open-minded.

Unfortunately, this first golden age for the discipline couldn't last. The Italian scholar Croce's fierce attack on the discipline's comparative methodology and lack of scientificity, and some famous comparatists in French school, such as Baldensperger, Paul Van Tieghem, Guyard, took the lead to throw off the much-clouted "arbitrariness" in comparative literature practice to gain "certainty" and "scientificity" which were then unprecedentedly respected in all academic communities. The discipline consequently was diminished from a vast research area into smaller confines. The French school gave up the good beginning of open-mindedness and fine tradition of diversity of research objects and plunged itself into the study of "international literary relation." The narrowed set of objects of study enabled the discipline to successfully dodge the arrows from Croce but paid the price of freedom. The over-tight control of study object greatly limited the development of comparative literature study. Although France, as an old-brand big literary power, made considerable achievement in influence studies, other nations which were comparatively weak global influence of literature benefited little. Especially, this research pattern did not bring any privilege to America which once was traditionally weak in literature but later rose as a new power. The narrowed study objects confined to positive influence and relationality made comparative literature study less relevant to scholars outside France. Besides, the abandonment of the comparative method led to continual confusion for scholars external to the field. Moreover, the employment of positive methodology gained scientificity but made the discipline deprived of literariness and aestheticism. As Wellek's claim of literariness as "the central issue of aesthetics, the nature of art and literature"(Wellek 282-295) as Theory of Literature and A History of Modern Criticism became widely accepted, the French school's narrowly focused domain of objects of study showed its limitations since it only built a foundation of empirical and external relations. Besides, Bassnett's view was representative of many comparatists. She found through her undergraduate dissertation on James Joyce's influence on Italo Svevo that "writers' statements cannot be trusted, they are expressions of opinion and sometimes of deliberate deception. Influence is improvable" (Zhang "Where" 49). Two main trends in scholarship that had a decisive impact on the trajectory of the French school were the promotion of literariness, and the turn away from positivist aspirations. The fate of French comparative literature studies may offer some cautionary value about excessively narrowed objects of study for a discipline.

It is not only the French School that narrowed comparative literature study. Actually, although American school's study object was broader than that of its predecessor, there were similar trends in scholarship that produced similar limitations. In terms of study horizon, French school could not avoid a nationalist patriotism which consciously or unconsciously led it to pay more attention to those facts that proved French literature's omnipresent and continuous influences on literature of other nations than on anything else. French school's nationalism inevitably led it to a narrowed horizon in their study. Similar things happened in American school, too. It seems that the American school was free of such nationalist prejudice, but it should not be ignored that although parallel studies advocated by American comparatists seemingly place the two compared factors within the equilibrium of a scale, the weighed objects had to be from western civilization. In other words, their research only illuminated the literary production of Europe and North America. Literature out of western civilization is usually outside their research horizon. Even Weisstein once doubted the possibility of comparing literary works from different civilizations: "I am hesitant to expand the parallel study on literatures of different civilizations, because, in my view, commonalities in thoughts, emotions, and imaginations can only be 
discovered consciously or unconsciously within a single civilization" (Weisstein 5). It must be admitted that to focus solely on western civilization is a kind of conservatism that recapitulates to the narrowed comparative literature study in a new situation. Comparative study restricted only in western civilization betrays the disciplinary goal of Weltliteratur (world literature) hailed by Goethe as early as 1827 (Goethe 8). In fact, in 1993, Claudio Guillen appealed to comparatists to engage in literature study in the "supernational" realm which surpassed national and even international domains to challenge Eurocentrism (Challenge 70-71). He encouraged to set comparative literature free from present single civilization and welcomed the study of literature in a broader realm. In the beginning of the new millennium, David Damrosch provided an acceptable new definition for the old term coined by Goethe: "The term crystallized both a literary perspective and a new cultural awareness, a sense of an arising global modernity, whose epoch, as Goethe predicted, we now inhabit" (What 1-2). His remarks demonstrate that the goal of comparative literature in the 21st century includes not only the study of literature in western civilization or studying literature from western perspectives, but also includes the study of literature out of western civilization, some researching perspectives completely different from western tradition and accommodating literary works and theories in the whole world with a broad mind. In other words, in the global epoch which we now inhabit, academic specialization is incompatible with current reality. Only the implementation of comparative literature study from a broad horizon of "world literature" enables the discipline to remain viable and relevant.

In addition to the narrowing of study object and horizon, the narrowing of comparative literature study also lies in "comparability": one of the discipline's cornerstones. The French school's influence studies were built on the comparability of the "same origins." Doxologie, mesologie and crenologie can exist only if there were some shared origins among literature works in different nations. Therefore, its primary achievements were gained through researches ranging from motifs, themes, plots, and characters to settings derived from the same origin. Without "sameness," influence studies would be impossible. The American school's parallel studies were built on similar properties between literary works and theories across nations, languages, and disciplines. The term "parallel" itself denotes analogy, a device for the comparison of similar objects. But now in the era of globalization, though literary works and theories do share something in common, more frequently they display some conspicuous discrepancies. According to the disciplinary system established by the American school, the discrepancies are incomparable since nothing is inherently identical. They believe that comparability should be fixed with homogeneity instead of heterogeneity, which explains why they hesitate to expand their study horizon from western civilization to eastern civilization. Practices of comparative literature study by some scholars in the French and American schools have suggested that the stubborn entrenchment in sameness has a negligible effect on people of the same context, while those who set their sights on exotic literature which is in sharp contrast with their own literary tradition tend to enjoy international reputations. In this aspect, some European and American sinologists have set notable precedents. Wolfgang Kubin's translation and illustration of Chinese modern and contemporary literature, Kristofer Schipper's researches on Taoism, David R. Knechtges' great contribution to Han Fu (Han Prosody) and Stephen Owen's insight on Tang Poetry have brought pleasant surprises to not only to their compatriots but also Chinese literati. Enlightened and encouraged by their achievements, theorists of comparative literature study in the Chinese school make exploration in getting rid of the old-fashioned "toseek-sameness" model and building comparative literature study on comparability of heterogeneity. In 2013 book, "The Variation Theory of Comparative Literature" by Professor Cao Shunqing, has triggered scholars' reflections on the discipline's new tendency at home and abroad. In the book, Cao claimed that "based on positivism, the study of variations of comparative literature is a new perspective in influence studies. It objectively studies the dynamic development of literature, penetrates the development of literature through variation, and combines positivism of the French school with the study of variation. This approach is a response to some of the perceived shortcomings of the French school, which enriches and supplements the model of influence studies and also greatly pushes the development of the theory of comparative literature" (Cao, "Variation" 43). Douwe Fokkema writing in the book's foreword that "the Variation Theory is an answer to the one-sided emphasis on influence studies by former 'French school' as well as to the American focus on aesthetic interpretation, inspired by New Criticism, which regrettably ignored literature in non-European languages" (Cao, "Variation" V). In 2015, Svend Erik Larsen published a book review in Orbis Litterarum and concluded: "the book is an invitation to enter into a dialogue with established Western comparatism" ("Shunqing" 437-438). And he added that the time was ripe for dialogue because of these overlapping research interests in world literature studies, translation studies, genre studies, studies of the political, studies of the posthuman, studies of digital media and literatures. The unique and original variation theory molded 
on the basis of comparatists' practices on heterogeneous literature now has drawn many peers' attention and has conversely been guiding an abundance of practices in the field of comparative literature worldwide. Chinese and Western scholars alike have taken interest in the comparability of differences. Already Ulrich Weisstein wrote in Comparative Literature and Literary Theory (1973) that "instances of literal imitation are probably rarer than more or less creative transmutations" (31). "Creative transmutation" here later is admitted by Cao Shunqing "close to the concept of variation" (Cao). In 2006, Thomas Docherty, after remarking on Franco Moretti's employment of a "tree" or "wave" to metaphorically demonstrate that comparative literature had an overemphasis on "uniformity", he inquired: "What, however, if the task of Comparative Literature is the task of producing difference as such? What if we entertain the possibility of real diversity, as it were? What if there is a diversity that cannot be regulated under the sign of any uniform?" ("Without" 32) It's obvious that both western and eastern comparatists have begun to notice the comparability of heterogeneity brought by crosscivilizational literary exchanges. Noticeably, to construct a completeness of comparative literature study on comparability of both homogeneity and heterogeneity is the ultimate goal of both western and eastern comparatists.

The noun phrase "comparative literature" is made up with a modifier "comparative" and a head "literature." But along with so-called cultural turn, the academic current of humanities research in the late twentieth century presented a phenomenon of "pan cultural study." Literature, once an indispensable and central element in comparative literature study, then became not as significant as before when the discipline was enveloped in the umbrella term "culture." Since the connotation of "culture" comprises so broad a sense of almost all the knowledge and values shared by a society that "literature," the once privileged study object in comparative literature study, is dwarfed when lining up with some other research objects, such as gender, politics, post-colonialism, etc. Bernheimer, for example, called for a shift in perspective from literature to culture for comparative literature in an age of multiculturalism (Bernheimer 1-17). In Anton Pokrivčák's words, Bernheimer, contrary to Wellek, "proposed a different solution to the crisis - to leave the intrinsic world of literature and have comparisons enter the fields of media, economy, politics, etc" (Pokrivčák 77-78). However, in the fashion of culture study, there are still some other scholars alerting to its danger. For instance, in "Whither Comparative Literature?" (2006), Jonathan Culler pointed out: "comparative literature liberated itself from the study of sources and influence and acceded to a broader regime of intertextual studies broader but less well-defined"(85). His criticism, that the expansion of comparative literature to global cultural studies is to incur another crisis of its identity, cannot be overstated. In 2009, Czech scholar Ivo PosPíšIl concluded that "Comparative literary studies, might more than in the past, dissolve into other disciplines, or may function as a more-or-less compact discipline in a wider framework of cultural and area studies" ("Permanent" 57). Regardless of his process of argumentation, there is something in his conclusion. Just as what is analyzed above, if comparative literature gives up its core of "literature" and replaces it with a far more extensive object of "culture," the prediction that the discipline is to be dissolved into other disciplines carries more weight. In 2010, Zhang Longxi shared Culler's concern, as shown in his observation that without literature, "comparative literature" would lose its peculiarity and encounter its identity crisis. He asserted in "The Coming Era of Weltliterature" that comparatists needed to return to literature in the further development of literature study after the turbulence stirred by culture studies (Zhang 194). Wang Ning also noticed the danger in the same year and said: "many research fields originally belonging to the discipline of comparative literature are now either occupied by cultural studies scholars or cultural critics" (Wang, "Crisis" 29). In 2013, ideological approaches to the study of literature were denied by Anton Pokrivčák, and "interliterariness" was assumed as one of the possible ways to find a balance between "contextualizations of literature in ideological and cultural terms remain aware of literature's institutional definitions" by Peter Brooks in his article "Must We Apologize?" (in Bernheimer, Comparative 97-106). He advised that the formalist term of literariness be preserved if literary scholars did not wish to "commit suicide" and deprive the field of critical scrutiny of the aesthetic treatment of the human condition. He also believed literariness would need to become interliterariness if comparative literature were to preserve its spirit of comparison and thus not to give up addressing the particular within the universal (Pokrivčák, "Comparatism" 77-88). From Claudio Guillen, Jonathan Culler, Ivo PosPíšIl, Zhang Longxi, Anton Pokrivčák's observations and reflections, over-generalized "comparative culture study" upset the balance between "the particular" within "the universal", making literature, the particular, invisible in culture, the universal, because the latter increasingly threatens and vulgarizes the former. Therefore, comparatists should be aware of the subtlety and fragility of the balance between literature and culture, avoiding the risk of engulfment within pan-cultural studies. Besides, even if scholars like Gayatri 
Spivak and Edward Said have made tremendous achievements in their paradigm of blending literature study with more comprehensive cultural studies, the question of placing their work in the category of comparative literature is suspended by some comparatists internationally, because of the complex symbiotic relationship between cultural studies and literature studies, since comparative literature study can be carried on neither void of researches on culture, society, or ideology nor lack of literature. It is not an exaggeration that the new crisis of "less well-defined" or "to be dissolved" is just an aftermath of pan-cultural studies encroachment into comparative literature studies.

Besides the crisis caused by pan-cultural studies, the discipline is now afflicted by a cliché. Due to Croce's accusation, Guyard once expressed his understanding of "comparative literature" in his la Littérature Comparée by denying the discipline's relation with comparison (Guyard 5). French school's compromise of giving up "compare" temporally found a shelter for the discipline with its old enemy lurking outside. Expectedly, after "compare" was resumed by American school's parallel studies, its comparative methodology fell victim again. Thomas Docherty in "Without and Beyond Compare" advised to give up "comparison" as a research paradigm. His article ended with "This event of an encounter, like love, is what is without and beyond compare" (Docherty 34). In his words, using Badiou's "encounter" or "love", as the existence of a third position that transcends the two compared positions, to substitute "compare" which usually brings bias and the supremacy of a third position is a proper way to get out of the predicament caused by "compare" in comparative literature study. But can comparative literature develop without or beyond compare? As discussed above, "comparative literature" is composed of the modifier "comparative" and head "literature." Without the modifier, "comparative", the original phrase becomes a general noun. Undoubtedly, losing the qualifier of "comparative", "comparative literature" cannot find its specific horizon and will be engulfed by a more general definition of "literature study." So abandonment of "compare" is also a kind of "overgeneralization" which bogs down the discipline in the crisis of "less well-defined" or "to be dissolved." Moreover, the polysemy of "compare" in the new age should be duly recognized. In addition to its previous meaning of comparing similarities and contrasting differences, it should cover more patterns, including cultural filtration, misreading, mistranslation, deformation of images and domestic appropriation in literary works and theories' dissemination and reception. Only through adhering to and evolving "compare" instead of abandoning it can "comparative literature" withstand so many slings and arrows.

The last population the bell tolls for are those who oversimplify the study of comparative literature. A literal understanding of the designation constantly misleads practitioners, especially newcomers, to simplify the study into a comparison of "X+Y." Due to this improper simplification, some fruitless comparative literature researches based on superficial similarities or differences were popular in China. For example, Zhao Jingshen's summarization of some coincidences between Chinese playwright Tang Xianzhu and Shakespeare in their life experiences and composition of plays was criticized for its incompetence of deepening our understanding of the two great literati's thoughts on their respective national characteristics or their personal styles. Analogically, Fang Ping's conclusion that some "unkind" characters can be endowed with aesthetic value and artistic charm drawn through comparison between Falstaff in Shakespeare's plays and Wang Xifeng in "Dream of the Red Chamber" also incurred negation. The deficiency of trivialization in the examples listed above was once evident and can be easily detected in many early researches, but fortunately, this " $\mathrm{X}+\mathrm{Y}$ " pattern of comparative literature study is consciously avoided now.

Trivialization is also embodied in a kind of "monologue" in comparative literature study. As we know, comparative literature study's priority, against the background of "literature study" is it objective to "cross", nations, languages, disciplines, or civilizations, so the study innately involves itself with two or more research objects. The early French school's influence studies were mostly about French literary works or theories' monologue to literature in other nations. Out of patriotism or national pride, French literature was usually the confident patriarchic speaker, with his obedient descendents silently submitted to his authority. Then along with the rise of America, in a long period of time, even now, America has taken the position to be the eldest brother who substituted his predecessor and be the dominant voice in the family of world literature. It looks that monologue-like studies from perspective of "developed" countries' influences on underdeveloped countries thrive out of the necessity of contending for "discourse power". But what can be looked through from the superficial prosperity is the ontologically literary independence and insufficiency which is deeply harmed by its counterparts: politics and economy. Therefore, to make comparative literature study escape the manipulation of economy or politics, monologue, a new form of colonialism, must be shunned. Only a dialogue-like pattern under the principle of "diversity in uniformity" which tolerates both sides to voice their literary 
ideals and understandings can ensure the intensive and extensive meaning of comparative literature study.

Taking China's reception study as an example, due to some overt historical reasons, China has remained a willing listener in literature exchanges since the early eighteenth century. In the acceptance and imitation of the discourse of the Soviet Union or America, it has almost forgotten how to voice with its own traditional terminology or theories, which was metaphorically called "aphasia." Chinese scholar Wang Ning's words recently expressed his dissatisfaction: "Chinese literary theories have been shadowed by western literary theories for a long time......though some variation occurs in the theory travel, the travel has all the way been unidirectional, i.e. from west to east" ("From" 127). Obviously, a monologue-like pattern in comparative literature study is unwelcome to most western and eastern comparatists, especially when literature is rising along with a country's economy and politics in the international community.

A third form of trivialization is to equate comparative literature with its method, i.e. the study of literature via comparison." In fact, any research of a specific discipline's self-degradation to its methodology unexceptionally leads to trivialization. Even if a study of natural science, no matter how strictly it requires scientificity, it is still not lack of some "romantic" ideals. Comparative literature, as a study in humanities and social science, must not be deprived of its romantic ideal-"world literature." If comparatists only indulge themselves into some trivial and odd studies of comparison without an ultimate goal of "world literature," they can hardly keep their zeal in their academic career and may easily lose their interest to explore new possibilities in their study. Weltliteratur, once only a utopian ideal in Gothe's age, now becomes more and more tangible with the deconstruction of cultural monopoly, the ascent of the Third World in politics, economic globalization, convenience in transportation and information access. Without the cosmopolitan ideal of Weltliteratur to navigate by, comparative literature studies can become a rudderless pedantic exercise for bookworms. Those who feel pessimistic towards the discipline are partly those who lose their beacon, world literature.

In the middle of the twentieth century, Qian Zhongshu, a forerunner of Chinese comparative literature, once said in his masterpiece Tan Yi Lu(《谈艺录》) that "both oriental and occidental people share the same law thought; both south and north school share the same rule of learning" (东海西海, 心理敒 同 ; 南学北学, 道术未裂) (Qian, Tan preface). He expressed his firm belief in the discovery of a common poetic axiom that governed literary and artist creation and criticism throughout the world. Marx and Engels also proclaimed in The Communist Manifesto (1948) that "National one-sidedness and narrowmindedness become more and more impossible, and from the many national and local literatures, a world literature arises" (Marx 276). In the beginning of the twenty-first century, Franco Moretti, author of Conjectures on World Literature (2000), proposed that "That's the point: world literature is not an object, it's a problem, and a problem that asks for a new critical method: and no one has ever found a method by just reading more texts. That's not how theories come into being; they need a leap, a wager-a hypothesis, to get started" (54). It is evident that Franco Moretti has developed world literature from a simple abstract ideal to a concrete paradigm with which to meet the challenges of literature studies in a global post-industrialized world. Eva Kushner observed that "throughout its history, comparative literature has internalized as part of its own objectives and directives a major challenge: The need to renew its problematics and curriculums in response to the inherent diversity of literature within culture" ("Is Comparative" 1). She began to notice the trend to regard "world literature" as the potential material of comparative literature studies. Recently, Douwe Fokkma in World Literature (2007), David Damrosch in What Is World Literature (2003) and How to Read World Literature (2009), Wang Ning in "The Crisis of Comparative Literature and the Rise of World Literature" (2010), together with Theo D'haen and César Domínguez in World Literature: A Reader (2012) all contemplated the old coinage's huge potential to dismantle the deadlock in "comparative literature as a discipline." "World literature" is now held in hands of comparatists as an effective tool to accelerate the breakdown of eurocentrism and occidentalism. The new interpretation of world literature will equip comparative literature study with a potent tool for discerning provincial and universalist valences along their expansive research horizon.

A retrospect of the development of comparative literature study in the past helps us to precisely understand its status quo. The bell has been tolling for the sorts of scholarship and the limited grasp each exercises when it comes to comparative literature and the developments it needs to maintain currency in the new age: narrowing the study in the aspects of study object, scope, and comparability; overgeneralization through replacing comparative literature study with pan-cultural study and abandoning its comparative methodology, and lastly, the trivialization of the study via simplifying it into a comparison of " $\mathrm{X}+\mathrm{Y}$ " model, a developed country's "monologue" over its underdeveloped 
counterpart, and a pedantic practice void of Weltliteratur as both an academic ideal and a method for ensuring the discipline's continuation in perpetuity. Cautioned by these false cognitions and improper trials, international comparatists should consciously avoid these crises from these following aspects: firstly, work beyond the conventional eurocentrism and occidentalism, releasing the restrictions on objects of study and enlarging the research scope to the whole world to internationalize comparative literature studies. Secondly, admit the comparability of heterogeneity, employing variation theory to show the value of research on literature in transcultural dissemination. Thirdly, use cross-cultural study to replace pan-cultural study, avoiding being swallowed by the more extensive culture study to lose its identity. Fourthly, return to comparison and enrich its connotation in a new age. Fifthly, use dialogue to replace monologue in influence study or reception study to manifest equal positions between the two compared parties. Last but not least, redefine world literature as both academic ideal and methodology to settle the disciplinary controversies.

Note: This essay was produced with the Web Culture project "Case Study of Local Literature's Canonization in Network Environment from the SWOT Analysis" (网络环境下本土文学经典化案例 SWOT 分析) (WLWH17-41). It was Sponsored by the Humanities and Social Research Base of the Sichuan Provincial Education Department. I am grateful for their support for me to conduct the necessary research for this project.

\section{Works Cited}

Bassnett, Susan. Comparative Literature: A Critical Introduction, Oxford: Blackwell, 1993.

Bassnett, Susan. "Reflections on Comparative Literature in the Twenty-First Century." Comparative Critical Studies 1-2 (2006): 1-11.

Beker, Miroslav. "Is Comparative Literature in a Crisis?" Art of Words 2 (1998): 91-100.

Bernheimer, Charles. Comparative Literature in the Age of Multiculturalism, Baltimore and London: Johns Hopkins UP, 1995.

Cao, Shunqing (曹顺庆). The Variation Theory of Comparative Literature. Heidelberg: Springer, 2013.

Cao, Shunqing (曹顺庆). "Variation Theory and the Reception of Chinese Literature in the English-speaking World," CLCWeb: Comparative Literature and Culture17.1 (2015): <http://docs.lib.purdue.edu/clcweb/vol17/iss1/6/>.

Cao, Shunqing (曹顺庆) and Wang, Lei (王蕾) ."失败的预言 过时的药方" ("Failed Prediction and Outdated Prescription"). Chinese Comparative Literature (1) 2009:21-23.

Cavell, Richard A. "Comparative Canadian Literature as Crisis and Critique: Towards Comparative Cultural Studies." Textual Studies in Canada 5 (1994):7-14.

Culler, Jonathan. "Whither Comparative Literature?" Comparative Critical Studies, 2006. 85-97.

Damrosch, David. What Is World Literature? New Jersey: Princeton UP, 2003.

Docherty, Thomas. "Without and Beyond Compare." Comparative Critical Studies (2006): 25-35.

Goethe, Johann Wolfgang von. Werke. Weimarer Ausgabe, III. Abteilung. Goethes Tagebucher. Band 11. 18271828. Weimar: Hermann Bohlaus Nachfolger, 1900.

Guillen, Claudio. The Challenge of Comparative Literature, trans. Cola Franzen, Cambridge, Mass.: Harvard UP, 1933.

Guyard, Marius-Francois. Comparative Literature. Paris: French UP, 1951.

Kushner, Eva. "Is Comparative Literature Ready for the Twenty-First Century?" CLCWeb: Comparative Literature and Culture 2.4 (2000): <http://dx.doi.org/10.7771/1481-4374.1096>.

Larsen, Svend Erik. "Shunqing Cao. The Variation Theory of Comparative Literature." Orbis Litterarum (2015): 437-438.

Liu，Xiangyu (刘象愚). "比较文学'危机说'辨别" ("Reflections on the Crisis of Comparative Literature as a Discipline"). Journal of Peking University (Philosophy and Social Sciences) 3 (2008): 33-42.

Marx，Karl (卡尔·马克思) and Engels, Friedrich (弗里德里希·冯.恩格斯). 马克思恩格斯文集: 第 23 谷 (The Collected Works by Karl Marx and Friedrich Engels: Vol 23). Trans. and Ed. Central Compilation and Translation Bureau (中央编 译局编译). Beijing: Renmin P, 1972.

Moretti, Franco. "Conjecture on World Literature." New Left Review 1 (2000): 54-55.

Moser, W. "Comparative Literature and the Crisis of Literary Studies." Canadian Review of Comparative Literature 1 (1996): 43-50.

Pokrivčák, Anton. "Comparatism and the Crisis of Literary Studies." World Literature Studies 2 (2013): 77-88.

Pospisil, I. "The Permanent Crisis, Or Can, Could or Should Comparative Literary Studies Survive? Between History, Theory and Area Studies." World Literature Studies 1 (2009): 50-61.

Qian, Zhongsu (钱钟书). 谈艺录 (Tan Yi Lu).Shanghai: SDX Joint Publishing Company, 2001.

Roloff, HG and Pabisch, P. "Crisis or Future? The Germanic compared Literature - Literary Criticism - Literary Criticism." Jahrbuch Fur Internationale Germanistik 1 (2010): 9-10.

Saussy, Haun. "Exquisite Cadavers Stitched from Fresh Nightmares: Of Memes, Hives, and Selfish Genes." Comparative Literature in an Age of Globalization, Baltimore: Johns Hopkins UP, 2006.

Spivak, Gayatri. Death of a Discipline, New York: Columbia UP, 2003. 
Wang, Ning (王宁). "The Crisis of Comparative Literature and the Rise of World Literature." Comparative Literature East \& West 33 (2010): 29.

Wang, Ning（王宁）."从理论的（单向）旅行到（双向）对话" ("From Theoretical [Unidirectional] Travel to [Bidirectional] Dialogue"). Journal of Shenzhen University (Humanities \& Social Science) 5 (2016): 122-127.

Weisstein, Ulrich. Comparative Literature and Literary Theory: Survey and Introduction. Trans. William Riggan, Bloomington: Indiana UP, 1973.

Wellek, René. "The Crisis of Comparative Literature." Concepts of Criticism. New Haven and London: Yale UP (1964): 282-295.

Wolski, Paweł. "Comparative Studies Today. Comparative Studies, Crisis... " Literary Memoir 2 (2015): 250-254.

Zhang, Cha (张叉) \& Bassnett, Susan. "Where is Comparative Literature Going: An Interview with Professor Susan Bassnett." Comparative Literature and World Literature 1 (2016): 47-51.

Zhang, Longxi (张隆溪). "世界文学时代的来临" ("The Coming Era of Weltliteratur"). From Comparative Literature to World Literature. Shanghai: Fudan UP, 2010.

Author's profile: Jie Lu (卢婕) teaches English and American Literature at the Chengdu University of Information Technology and also studies comparative literature and world literature at the Sichuan University College of Literature and Journalism. Her interests in scholarship include comparative literature and translation studies. Lu's publications include: “从’易一名而含三义'看比较文学中国学派三十年发展" ("The Development of Chinese School of Comparative Literature over the Last Three Decades: Based on 'the Three Meanings Contained in Yi'"). Journal of Shenzhen University (Humanities \& Social Science) (2016), "本土文学的海外传播一一薛涛诗作的英语译介研究" ("Overseas Dissemination of Native Literature: Research on Translation of Xue Tao's Poetry in Anglophone World"). Cultural Studies and Literary Theory Vol.35. E-mail: <lujie@cuit.edu.cn> 